\title{
EFFECT OF MOLECULAR MASS AND SURFACE CHARGE OF ANIONIC POLYACRYLAMIDE ON PECTIN PRECIPITATION
}

\author{
Tatjana A. Kuljanin*1, Vladimir S. Filipović ${ }^{1}$, Milica R. Nićetin ${ }^{1}$, Biljana Lj. Lončar ${ }^{1}$, Violeta M. \\ Knežević ${ }^{\text {, Rada C. Jevtić Mučibabić }}{ }^{2}$ \\ ${ }^{1}$ University of Novi Sad, Faculty of Technology, 21000 Novi Sad, Bulevar cara Lazara 1, Serbia \\ ${ }^{2}$ University of Novi Sad, Institute of Food Technology, 21000 Novi Sad, Bulevar cara Lazara 1, Serbia
}

\author{
*Corresponding author: \\ Phone: +381214853667 \\ Fax+38121450 413, \\ E-mail address: kuljanin@uns.ac.rs
}

\begin{abstract}
In sugar industry, separation of undesirable compounds in sugar beet juice is done mostly by $\mathrm{CaO}$ and carbon dioxide. In order to reduce the amount of lime, a new method of pectin separation based on the application $\mathrm{CaSO}_{4}$ with the addition of various types of anionic polyacrylamides (PAMs) is presented. The effects of molecular weight (MW) and the surface charge type of anionic polyacrylamides on the pectin precipitation were investigated. These compounds cause the process of charge neutralization of pectin macromolecules, followed by two mechanisms of polymeric bridging effect: $\mathrm{Ca}^{2+}$ bridges between anionic polymer molecules and pectin particles that promote the coagulation of pectin and $\mathrm{Ca}^{2+}$ bridges between anionic polymers that hinder coagulation of pectin. The aim of this paper was to examine the effect of $\mathrm{CaSO}_{4}$ mixture and anionic PAMs of different molecular weights and degree of ionizaton to increase the efficiency of removal of pectin from sugar beet juice.

Two pectin preparations were isolated from sugar beet pulp. $\mathrm{CaSO}_{4}$ was added to $100 \mathrm{~cm}^{3}(0.1 \% \mathrm{wt})$ pectin solution. Studies were performed with 10 different concentrations of $\mathrm{CaSO}_{4}$ solution $(50-500$ $\mathrm{mg} / \mathrm{dm}^{3}$ ) with the addition of anionic PAM with two ionization degree and three molecular weight, concentrations of $3 \mathrm{mg} / \mathrm{dm}^{3}$. The efficiency of pectin precipitation was monitored by measuring the zeta potential. The bridging effect of $\mathrm{Ca}^{2+}$ ions between anionic PAMs and pectin has increased with an increase in the MW of the anionic PAMs. Using anionic PAM of the largest MW $\left(1500 \cdot 10^{6} \mathrm{~g} / \mathrm{mol}\right)$ and a lower degree of ionization (30\%), the optimal amounts of $\mathrm{CaSO}_{4}$ were measured: $340-355$ $\mathrm{mg} / \mathrm{dm}^{3}$. These optimal concentrations were achieved at the zero value of the potential zeta when the pectin particles were discharged.
\end{abstract}

Key words: pectin, $\mathrm{CaSO}_{4}$, anionic polyacrylamide, molecular weight, ionic degree

\section{INTRODUCTION}

Removal of impurities (consisting of both soluble and insoluble non-sugar compounds) from sugar beet juice by clarification is an essential part of the process of raw sugar manufacture.

Traditional inorganic salts of polyvalent metals and their polymers have been used for decades as coagulants in various pro- cesses of separation due to their advantages, above all, due to low prices.

With various coagulation-flocculation processes, the multivalent metals are adsorbed onto negatively charged colloidal particles (Yang et al., 2016). In the recent papers (Kuljanin et al., 2015a; Kuljanin et al., 2015b), a new method for separating 
pectin from sugar beet juice was presented based on the application of $\mathrm{CaSO}_{4}$ as well as cationic/anionic polymers. Pectins are classified as hydrocolloids due to their high molecular weight coupled with the abundance of polar and ionic groups on their sidechains.

One of the crucial properties of any food hydrocolloid is its ability to interact with water. In the mentioned papers (Kuljanin et al., 2015a) and (Kuljanin et al., 2015b), $\mathrm{Ca}^{2+}$ ions were used in the form of $\mathrm{CaSO}_{4}$ due to the known effect of dehydration of $\mathrm{SO}_{4}{ }^{2-}$ ions. This is, in addition to the charge neutralization of negatively charged pectin particles, a precondition for more rapid coagulation and precipitation hydrophilic pectin macromolecules (Garnier et al., 1994; Kuljanin et al., 2016). The main lack of inorganic coagulants is a high sensitivity to $\mathrm{pH}$, inefficiency in the separation of very fine particles and applicability to only a few dispersive systems (Yang et al., 2016).

It has been proved that the metal salts in the presence of small amounts of synthetic organic polymers (concentrations of $2-3$ $\mathrm{mg} / \mathrm{dm}^{3}$ of solution) achieve greater efficiency in separation of organic matter from wastewater (Pattabi et al., 2000). Synthetic organic polymers are macromolecules of chain structure with side chains at the ends of which are charged ionized groups. They can be anionic, cationic and neutral, depending on what kind of ions they bind to themselves. Polyacrylamide, which is most commonly used for purification of water, is effective at a concentration of $0.15-2 \mathrm{mg} / \mathrm{dm}^{3}$ in an aqueous environment having a pH of 3-7 (Karlovič, 2002).

By studying the conventional processing of sugar cane, it has been proven that after liming, adding anion flocculants (a high molecular weight copolymer of acrylamide and sodium acrylate) improves the sedimentation of non-sucrose particles in the juice. Also, the reduction of clarified juice turbidity by $50 \%$ was significant (Doherty et al., 2003). Authors found out that the anionic flocculants are more effective in the presence of cationic polymers to aid flocculation of the cane sugar juice particles. Studies on silica present in cane su- gar juice, suggesting that the uncharged polar amide groups in anionic flocculant (copolymer of acrylamide) are important in binding to silica (Mühle and Dobias, 1993). Industrial research on the classic cleaning raw sugar beet juice, using anion flocculants based on polyacrylamide, confirmed the technological and economic feasibility of this process (Loseva, 1990). Also, anionic polyelectrolyte proved to be very efficient for separation of proteins from crop (Baraniak et al., 2009). In the paper (Kuljanin et al., 2015a), the efficiency of the cationic and anionic polymers in the presence of $\mathrm{CaSO}_{4}$ was compared. The anionic polymers, which had less molecular weights $\left(10^{6}-7 \cdot 10^{6}\right.$ $\mathrm{g} / \mathrm{mol}$ ), showed a somewhat weaker effect of purifying pectin solutions than cationic polymer of higher molecular weight $\left(5 \cdot 10^{6}\right.$ $1.5 \cdot 10^{7} \mathrm{~g} / \mathrm{mol}$ ). For the cationic polymer, the charge neutralization mechanism it is considered to be predominant since most colloidal particles in aqueous solutions are negatively charged (Duan and Gregory, 2003; Kuljanin et al., 2015b). However, it has been established, both for non-ionic as well as for linear ionic polymers with large molecular weights and low charge charges, that the main mechanism for binding with colloidal particles is interparticle bridging (Ghimici and Nichifor, 2018). Anionic polyelectrolytes must have a large molecular weight (minimum of $10^{6}$ $\mathrm{g} / \mathrm{mol}$ ) to obtain a high enough kinetic energy to overcome the energy barrier between the negatively charged particles by mechanism of interparticle bridging (Koper, 2007; Kuljanin et al., 2016). The charge density (which depends on the degree of ionization) of polyelectrolyte has been studied so far only in the treatment of water and wastewater/sludge. In the reference (24), the influence of the charge density and the molecular weight of different polyelectrolytes on the precipitation of bentonite in wastewater were revealed. In the Results and Discussion section, references (Fraj, 2016) and (Yang et al. 2016) refer to the influence of the molecular weight of the polyelectrolyte (i.e. the length of their molecular chains) and their relationship with the degree of ionization at the molecular level during the treatment of water. Shaikh et al.,2017, 
were investigated the influence of surface charge density and molecular weight of anionic polyacrylamide (PAM) on the zeta potential and adsorption/flocculation behavior of highly stable bentonite dispersions. Authors found out that molecular weight was an essential factor influencing sedimentation and flocculation. Also it was concluded that flocculation decreased with increasing anionic surface charge density. To measure the charge of the surface of pectin particles, in this paper a method of measuring of the zeta potential was used. In the earlier works, a less precise method was used: a "jar" test based on measuring the time required for sediment sedimentation. Zeta potential is an electrokinetic parameter by which the charge of the surface of the colloidal particles can be measured. When the zeta potential reaches a value of $0 \pm 5 \mathrm{mV}$, the surface of the particles becomes discharged, allowing their precipitation (Koper, 2007; Kuljanin et al., 2016).

The main objective of this research was to investigate the effects of anionic flocculants with different molecular weight and ionization degree on pectin separation by $\mathrm{Ca}^{2+}$ ions. A series of anionic PAMs with different charge densities and molecular mass were used as a model compounds for synthetic anionic polyelectrolytes.

\section{MATERIALS AND METHODS}

Two pectin preparations are isolated from the pressed sugar beet pulp (Beta vulgaris L. ssp. Vulgaris var. Sacchariferra) after the industrial processing of sugar beet in sugar factory Šajkaška, Žabalj, Serbia. For the experiment, coagulant calcium sulfate in crystalline hydrate form $\left(\mathrm{CaSO}_{4} \times 7 \mathrm{H}_{2} \mathrm{O}\right)$ as an aqueous solution, produced in Zorka Pharma, Šabac, Serbia was used. Purity of this salt was $99.0 \% \mathrm{w} / \mathrm{w}$. As a flocculant, anionic polyelectrolyte, polyacrylamide, PAM, formula: $\left[-\mathrm{CH}_{2}-\mathrm{CH}\left(\mathrm{CONH}_{2}\right)\right]_{n}$ was used. The main technical parameters of the flocculant used are: purity, $90 \%$; middle degree of ionization were $30 \%$ and $60 \%$; values of mean molecular weight were $500 \cdot 10^{6}, 1000 \cdot 10^{6}$ and $1500 \cdot 10^{6}$ $\mathrm{g} / \mathrm{mol}$. Manufacturer: Zhengzhou Jing Lian; Water Purification Materials Co., Ltd., Henan, China (Mainland). The $\mathrm{pH}$ of the solutions was measured on a $\mathrm{pH}$ Meter MA 5740, "Iskra", Kranj, Slovenia.

\section{Pectin extraction}

As in previous work (Kuljanin et al., 2015a and Kuljanin et al., 2015b), 2 or 3 types of pectin preparations with different degrees of methyl esterification (DE) were used. Due to these differences, preparations P1 and $\mathrm{P} 2$ differed in the number of free $\mathrm{COOH}^{-}$groups (third column in Table 2) which depends on the charge of the surface of the pectin particles and therefore of the binding capacity of the $\mathrm{Ca}^{2+}$ ions. In this way, two pectic preparations with different coagulation capabilities were obtained. Pectin preparations $\mathrm{P} 1$ and $\mathrm{P} 2$ were isolated by extraction by standard laboratory procedure, AOAC (2000). Two types of preparations were isolated by extraction in acidic conditions. The $\mathrm{pH}$, temperature and duration of the extraction were made for preparation $\mathrm{P} 1 \mathrm{pH}=1.0, \mathrm{t}$ $=75{ }^{\circ} \mathrm{C}, \mathrm{T}=1.0 \mathrm{~h}$, while for preparation $\mathrm{P} 2: \mathrm{pH}=3.5, \mathrm{t}=95^{\circ} \mathrm{C}, \mathrm{T}=1.5 \mathrm{~h}$.

The extraction procedure is described in the previous paper (Kuljanin et al., 2014). The extraction of each preparation was carried out 3 times in order to obtain as precise as possible results of the measurement of the mean value of the dry matter content, the mean value of preparation purity (i.e. the galacturonic acid content), etc. The analysis of the basic parameters was performed in accordance with the standard method AOAC (2000). The degree of esterification of the obtained pectin preparations was calculated using the equivalents of free $(X)$ and esterified carboxyl groups (Y) (Kuljanin, 2008).

\section{Experiment plan}

The experiment examined the model solutions of pectin preparations of a concentration of $0.1 \%(\mathrm{w} / \mathrm{w})$. The working solutions were obtained by dissolving $1 \mathrm{~g}$ of the pectin preparation in $250 \mathrm{~cm}^{3}$ of distilled water and allowed to swell overnight. After that, they were complemented by distilled water up to $1 \mathrm{dm}^{3}$ and each measurement was separated by 50 $\mathrm{cm}^{3}$. After dissolving $1 \mathrm{~g}$ of $\mathrm{CaSO}_{4}$ in 200 $\mathrm{cm}^{3}$ of distilled water, the appropriate amount was taken with pipette and added 
to a $50 \mathrm{~cm}^{3}$ pectin solution $(0.1 \%$ by weight).

The resulting concentrations of $\mathrm{CaSO}_{4}$ are in the range of 50 to $500 \mathrm{mg} / \mathrm{dm}^{3}$. All measurements were carried out at $\mathrm{pH}=7$. After adding $\mathrm{CaSO}_{4}$ coagulant to a solution of pectin preparations and adjus-ting the $\mathrm{pH}$, the solution was mixed intensively for 30 min using a magnetic stirrer (Tehnica, Železniki, MM-520, Slovenia).

After dilution of the solution for $5 \mathrm{~min}$, thezeta potential of the clear part of the solution was measured (Table 3).

In the second phase of the experiment, after addition of $\mathrm{CaSO}_{4}$, flocculant anionic polyacrylamide (PAM), concentration $3 \mathrm{~g} / \mathrm{dm}^{3}$ was added. The mean molecular weigh tof PAM was determined refractometrically and spectrophotometrically by the Kar and Arslan method (Kar and Arslan, 1999). The mean molecular weight was obtained from experimental measurements for five different PAM concentrations.

Table 1.

Experiment plan

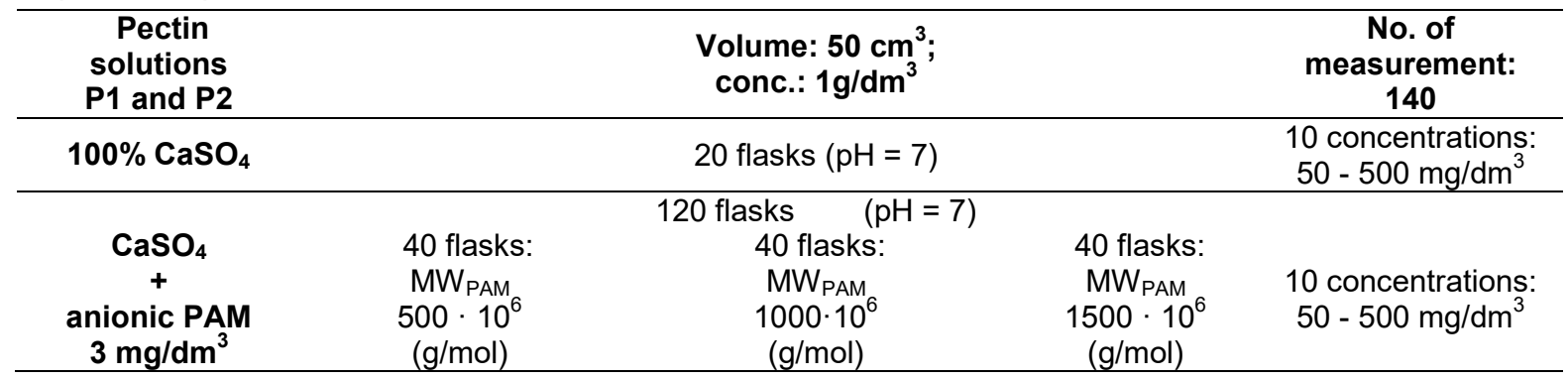

Table 2.

Physical-chemical properties of pectin preparations

\begin{tabular}{cccccc}
\hline $\begin{array}{c}\text { Type } \\
\text { of } \\
\text { pect. }\end{array}$ & $\begin{array}{c}\text { Solid } \\
\text { content SC } \\
\mathbf{( g / 1 0 0 g )}\end{array}$ & $\begin{array}{c}\text { Equivalent of free } \\
\text { COOH groups } \\
\mathbf{X} \cdot \mathbf{1 0}^{5}\end{array}$ & $\begin{array}{c}\text { Equivalent of } \\
\text { ester. COOH } \\
\text { groups } \\
\mathbf{Y} \cdot \mathbf{1 0}^{5}\end{array}$ & $\begin{array}{c}\text { Content of } \\
\text { galacturonic acid } \\
\mathbf{( \% )}\end{array}$ & $\begin{array}{c}\text { Degree of } \\
\text { esterification DE } \\
(\%)\end{array}$ \\
\hline P1 & 81.55 & 16.83 & 19.74 & 63.45 & 53.98 \\
P2 & 80.35 & 24.58 & 16.05 & 72.24 & 39.50 \\
\hline
\end{tabular}

Table 3.

Measured zeta potentials $(\mathrm{mV})$ of pectin solutions with $\mathrm{CaSO}_{4}$, treated with different $\mathrm{MW}$ and ionic degree of anionic PAMs

\begin{tabular}{|c|c|c|c|c|c|c|c|c|c|c|c|c|c|c|}
\hline \multirow[t]{3}{*}{$\begin{array}{l}\text { Conc. } \\
\mathrm{CaSO}_{4} \\
\left(\mathrm{mg} / \mathrm{dm}^{3}\right)\end{array}$} & \multicolumn{2}{|c|}{$\begin{array}{c}\text { Pure } \\
\mathrm{CaSO}_{4} \\
\text { (mV) }\end{array}$} & \multicolumn{2}{|c|}{$\begin{array}{c}\mathrm{CaSO}_{4} \\
+ \\
\text { anionic } \\
\text { PAM }\end{array}$} & \multicolumn{2}{|c|}{$\begin{array}{c}\text { MW: } \\
500 \cdot 10^{6} \\
(\mathrm{~g} / \mathrm{mol})\end{array}$} & \multicolumn{2}{|c|}{$\begin{array}{c}\mathrm{CaSO}_{4} \\
+ \\
\text { anionic } \\
\text { PAM }\end{array}$} & \multicolumn{2}{|c|}{$\begin{array}{c}\text { MW: } \\
1000 \cdot 10^{6} \\
(\mathrm{~g} / \mathrm{mol})\end{array}$} & \multicolumn{2}{|c|}{$\begin{array}{c}\mathrm{CaSO}_{4} \\
+ \\
\text { anionic } \\
\text { PAM }\end{array}$} & \multicolumn{2}{|c|}{$\begin{array}{c}\text { MW: } \\
1500 \cdot 10^{6} \\
(\mathrm{~g} / \mathrm{mol})\end{array}$} \\
\hline & \multirow[t]{2}{*}{ P1 } & \multirow[t]{2}{*}{ P2 } & \multicolumn{2}{|c|}{$\begin{array}{c}\text { Ionic } \\
\text { degree } \\
60 \% \\
(\mathrm{mV})\end{array}$} & \multicolumn{2}{|c|}{$\begin{array}{c}\text { Ionic } \\
\text { degree } \\
30 \% \\
(\mathrm{mV})\end{array}$} & \multicolumn{2}{|c|}{$\begin{array}{c}\text { Ionic } \\
\text { degree } \\
60 \% \\
(\mathrm{mV}) \\
\end{array}$} & \multicolumn{2}{|c|}{$\begin{array}{c}\text { Ionic } \\
\text { degree } \\
30 \% \\
(\mathrm{mV})\end{array}$} & \multicolumn{2}{|c|}{$\begin{array}{c}\text { Ionic } \\
\text { degree } \\
60 \% \\
(\mathrm{mV})\end{array}$} & \multicolumn{2}{|c|}{$\begin{array}{c}\text { Ionic } \\
\text { degree } \\
30 \% \\
(\mathrm{mV}) \\
\end{array}$} \\
\hline & & & P1 & P2 & P1 & P2 & P1 & P2 & P1 & P2 & P1 & P2 & P1 & P2 \\
\hline 50 & -22 & -21 & -20 & -20 & -20 & -19 & -19 & -20 & -20 & -20 & -20 & -19 & -20 & -19 \\
\hline 100 & -18 & -17 & -18 & -17 & -17 & -16 & -17 & -18 & -19 & -18 & -18 & -18 & -17 & -17 \\
\hline 150 & -17 & -13 & -15 & -14 & -15 & -15 & -15 & -16 & -16 & -16 & -16 & -15 & -15 & -13 \\
\hline 200 & -16 & -12 & -12 & -12 & -14 & -13 & -11 & -12 & -15 & -13 & -12 & -13 & -11 & -9 \\
\hline 250 & -13 & -11 & -11 & -10 & -11 & -10 & -10 & -10 & -11 & -9 & -8 & -8 & -7 & -5 \\
\hline 300 & -10 & -8 & -8 & -7 & -8 & -6 & -7 & -6 & -9 & -7 & -7 & -5 & -4 & -1 \\
\hline 350 & -7 & -6 & -5 & -3 & -4 & -3 & $-3^{x}$ & $-3^{x}$ & $-2^{x}$ & $-1^{\pi}$ & $-1^{\star}$ & $0^{\pi}$ & $0^{*}$ & +1 \\
\hline 400 & -3 & $-1^{*}$ & -3 & $-1^{*}$ & $-1^{\pi}$ & $-1^{\pi}$ & $+6^{\pi}$ & $+4^{*}$ & $+4^{*}$ & $+2^{*}$ & $+1^{\pi}$ & 2 & +1 & +2 \\
\hline 450 & $-1^{\pi}$ & $+3^{*}$ & $0^{*}$ & $+2^{\pi}$ & $+1^{\pi}$ & $+4^{\pi}$ & +7 & +5 & +5 & +5 & +3 & +3 & +4 & +3 \\
\hline 500 & $+4^{\pi}$ & +5 & +2 & +5 & +4 & +6 & +8 & +6 & +7 & +6 & +5 & +5 & +6 & +5 \\
\hline
\end{tabular}

The numbers marked with * represent the interval of the zeta potential: $0 \pm 5 \mathrm{mV}$ 
The basic solution was obtained by dissolving $0.5 \mathrm{~g}$ of PAM in $100 \mathrm{~cm}^{3}$ of distilled water and allowed to swell overnight at room temperature. From this solution, a solution of $3 \mathrm{mg} / \mathrm{dm}^{3}$ concen-tration was prepared. This solution was added to the solution of the pectin preparation according to the method described in the paper (Kuljanin et al., 2014).

\section{Measurement of the zeta potential}

The zeta potential of particles in a pectin solution was evaluated by means of electrophoresis using a Zeta Meter ZM-77 (Riddick, 1968). The process of measuring of zeta potential and general arrangement of Zeta Meter Unit was explained in the work (Alkan et al., 2005).

\section{RESULTS AND DISCUSSION}

Due to differences in the extraction conditions $(\mathrm{pH}$, temperature and duration of the extraction), two types of preparations were isolated. The pectin preparations were of different composition and degree of esterification. The results of the analysis of the basic physical-chemical properties of the pectin preparations are given in Table 2. The content of galacturonic acid (degree of purity) and degree of esterification in the tested preparations corresponds to the average value of the pectin content and degree of esterification in the raw juice of the sugar beet.

The results of measurement of the zeta potential of pectin solutions $\mathrm{P} 1$ and $\mathrm{P} 2$ which have been treated with $\mathrm{CaSO}_{4}$, with different types of anionic PAMs (three MW and two ionic degree), are given in Table 3 . The results represent the mean value of 3 measurements.

After measuring the molecular weight of samples of anionic PAM, using refractometric and spectrophotometric methods, fractions with a mean molecular weight of approximately $500 \cdot 10^{6} \mathrm{~g} / \mathrm{mol}$, $1000 \cdot 10^{6} \mathrm{~g} / \mathrm{mol}$ and $1500 \cdot 10^{6} \mathrm{~g} / \mathrm{mol}$ were isolated.

Figures 1 and 2 are presented optimal concentrations of $\mathrm{CaSO}_{4}$ to achieve the zero value of the zeta potential. Measurements were performed with different types of anionic PAMs (three MW and two ionic degree) for pectin solution $\mathrm{P} 1$ and P2.

This type of anionic flocculant (PAM) of large molecular weight is being used, both in the treatment of various industrial wastewaters and in the treatment of waste waters of sugar factories. In the experiments, the used concentration of the anionic PAMs was $3 \mathrm{mg} / \mathrm{dm}^{3}$ since the highest efficiency of clarification was noticed in previous works by applying polyelectrolytes of this concentration (Kuljanin et al., 2015a, Kuljanin et al., 2015b).

Around the zero value of the potential zeta, the surface of the pectin particles is discharged, which allows their coagulation and precipitation. The measured optimal amount of $\mathrm{CaSO}_{4}$ coagulant prior to the addition of anionic polyelectrolytes required to achieve the zero value of zeta potential was $460 \mathrm{mg} / \mathrm{dm}^{3}$ for preparation $\mathrm{P} 1$ and $440 \mathrm{mg} / \mathrm{dm}^{3}$ for preparation P2 (into the header of Figure 1 and 2). In this case, there is a simple charge neutrallization mechanism. With the use of anionic flocculants, less quantities of this coagulant were required, which can be seen from Figures 1 and 2. The minimum amount of $\mathrm{CaSO}_{4}$ needed to achieve the zero value of the zeta potential was measured using the anionic PAM with the highest MW (1500 million $\mathrm{g} / \mathrm{mol}$ ) and a lower degree of ionization $(30 \%)$. These optimal amounts of $\mathrm{CaSO}_{4}$ were: 355 $\mathrm{mg} / \mathrm{dm}^{3}$, for preparation $\mathrm{P} 1$ and 340 $\mathrm{mg} / \mathrm{dm}^{3}$, for preparation P2. Comparing the results from Figures 1 and 2, it can be concluded that MW of this type of polymer has a more significant effect on the precipitation of pectin than the impact of the degree of PAM ionization. Observed at the molecular level, as explained in the text below, with an increase in the molecular weight of the PAM, the number of binding sites with $\mathrm{Ca}^{2+}$ ions increases.

This is explained with the extended conformation of the polymeric chains of PAM (Yang et al, 2016), which enables a greater "bridging effect", thereby improving the precipitation of pectin. In this case comes to an increase in the number of $\mathrm{H}$ connections with the COO- groups, which reduces the degree of PAM ionization. 
Tatjana A. Kuljanin et al., Effect of molecular mass and surface charge of anionic polyacrylamide on pectin precipitation, Food and Feed Research, 45 (2), 169-177, 2018

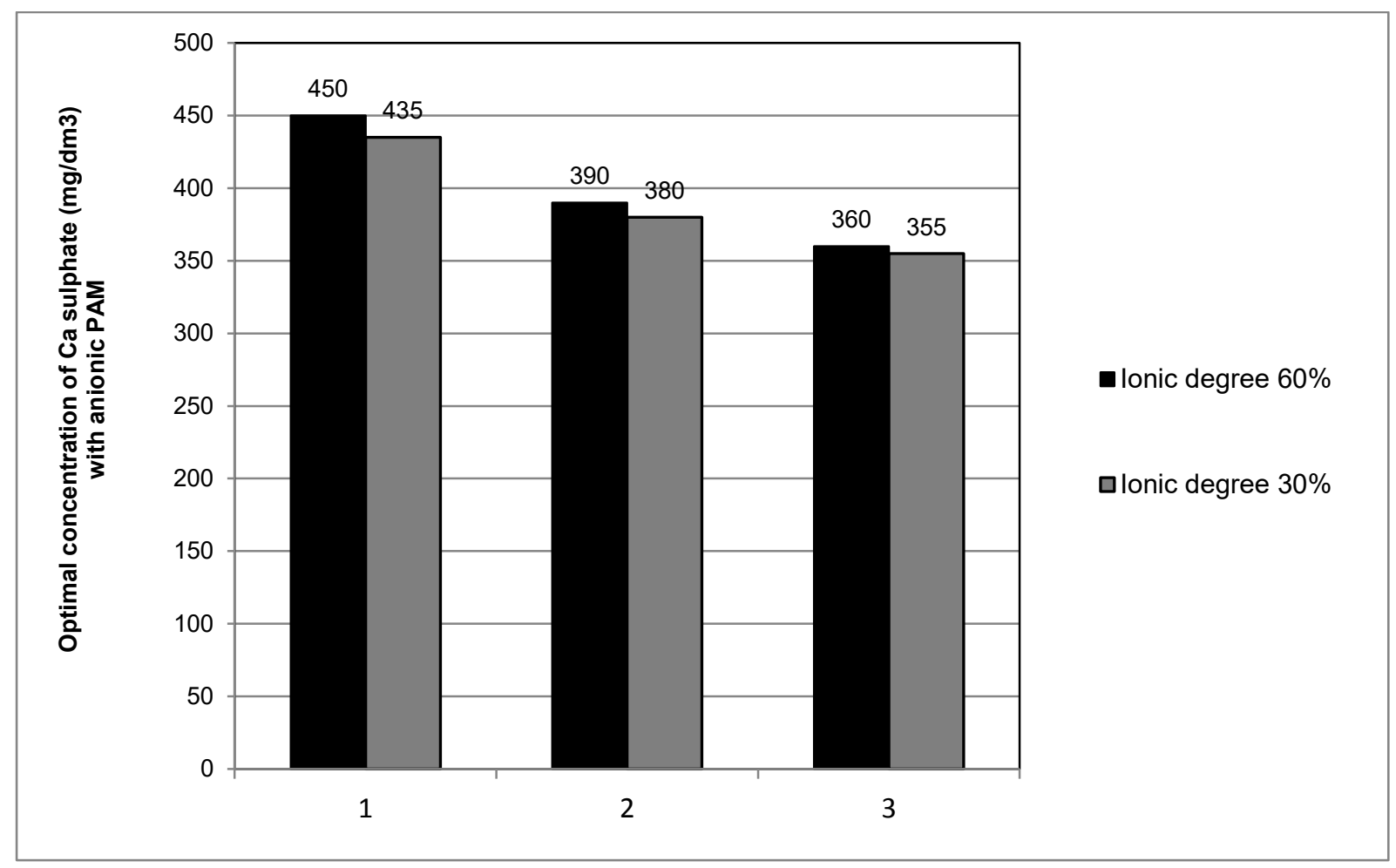

Figure 1. Optimal concentration of pure $\mathrm{CaSO}_{4}$ and $\mathrm{CaSO}_{4}$ with various types of anionic PAMs for pectin solution $\mathrm{P} 1$

Pure $\mathrm{CaSO}_{4}: 460 \mathrm{mg} / \mathrm{dm}^{3}$

Molecular weight of anionic PAMs: $1-500 \cdot 10^{6} \mathrm{~g} / \mathrm{mol} ; 2-1000 \cdot 10^{6} \mathrm{~g} / \mathrm{mol} ; 3-1500 \cdot 10^{6} \mathrm{~g} / \mathrm{mol}$

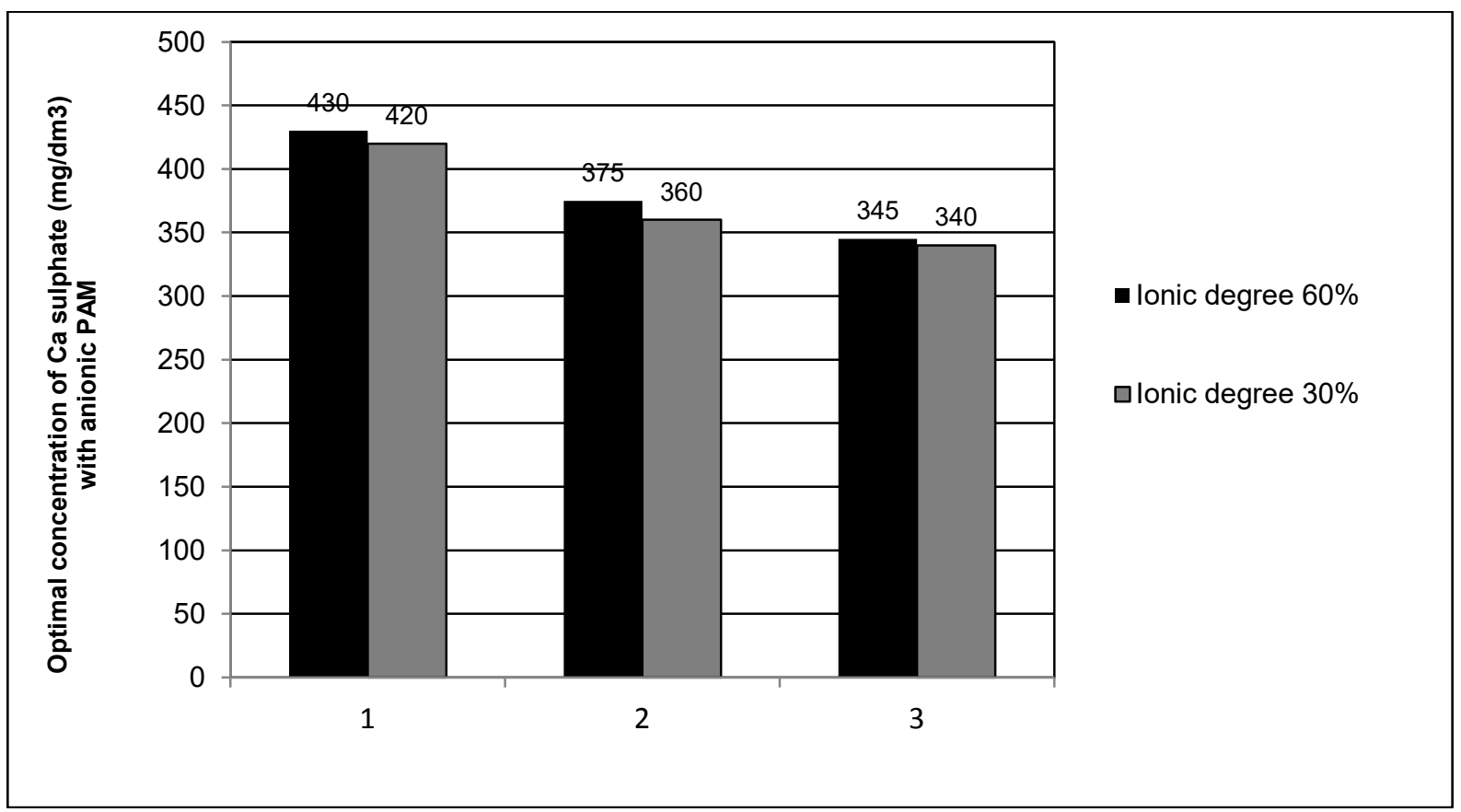

Figure 2.Optimal concentration of pure $\mathrm{CaSO}_{4}$ and $\mathrm{CaSO}_{4}$ with various types of anionic PAMs for pectin solution $\mathrm{P} 2$

Pure $\mathrm{CaSO}_{4}: 440 \mathrm{mg} / \mathrm{dm}^{3}$

Molecular weight of anionic PAMs: $1-500 \cdot 10^{6} \mathrm{~g} / \mathrm{mol} ; 2-1000 \cdot 10^{6} \mathrm{~g} / \mathrm{mol} ; 3-1500 \cdot 10^{6} \mathrm{~g} / \mathrm{mol}$ 
Namely, the optimal amounts of $\mathrm{CaSO}_{4}$ coagulants with the application of PAM of the same molecular weight and of a different degree of ionization, differed from 5 to $15 \mathrm{mg} / \mathrm{dm}^{3}$. The measured difference in the amount of coagulants with the application of PAM of different molecular weights and the same degree of ionization was in a significantly larger interval, from 100 to $105 \mathrm{mg} / \mathrm{dm}^{3}$.

The presence of $\mathrm{Ca}^{2+}$ ions suppresses the dissociation of functional groups of anionic polyelectrolytes and pectin macromolecules. Since $\mathrm{Ca}^{2+}$ ions have high efficiency in reducing electrostatic reflections between anionic polyelectrolytes and colloidal particles, they provide anchoring and bridging sites for anionic polymer molecules (Lee et al., 2012). In our case, $\mathrm{Ca}^{2+}$ ions build divalent cationic bridges between anionic polymer molecules and pectin particles. This can be schematically shown as: Pectin ${ }^{-} . .{ }^{+} \mathrm{Ca}^{+} \ldots{ }^{+} \mathrm{PAM}^{-} \ldots{ }^{+} \mathrm{Ca}^{+} \ldots$ Pectin.

In accordance with the literature data (Yang et al., 2016), only for large-MW flocculants is typical bridging mechanism. This "bridging effect" is strongly related to the structure of the polymer chains in water (i.e., the chain morphology and conformation). Increasing the $\mathrm{MW}$ of polymer usually results in a larger hydrodynamic size and a more extended conformation of the polymer chain. In our case, the bridging effect of $\mathrm{Ca}^{2+}$ ions (from $\mathrm{CaSO}_{4}$ ) will be enhanced with an increase in the molecular weight of the anionic polymer (Figure 1 and 2). Extended conformation of the polymer chains of PAMs allows for a higher number of $\mathrm{H}$-connections. The $\mathrm{H}$ bond is achieved when the $\mathrm{H}^{+}$ions from the amide group of polyacrylamide binds to the functional $\mathrm{COO}^{-}$ groups at the surface of the pectin particles. More amide groups on large-MW anionic PAM molecules allow stronger bonding between PAM and pectin macromolecules.

From literature (Fraj, 2016), it is known that the expansion of polymeric polyelectrolyte polymers occurs only to a certain value of the degree of ionization. In this experiment, in examined levels of ionization $(30 \%$ and $60 \%)$, the expansion of the polymer chain of PAMs was most likely negligible. This can explain the low impact of the degree of ionization of anion flocculant on the effect of coagulation and pectin flocculation.

Based on the literature data (Lee et al., 2012), it has been established that under certain conditions the opposite effect can be achieved that is, to increase the stabilization of the colloidal solution. In this case, are formed polymers - binding $\mathrm{Ca}^{2+}$ bridges, between PAM molecules. This can be schematically shown as: $\mathrm{PAM}^{-}$ ${ }^{+}{ }^{+} \mathrm{Ca}^{+} \ldots$ PAM $^{-} \ldots{ }^{+} \mathrm{Ca}^{+} \ldots$. PAM. This increased steric stabilization by developing polymer layers covering the pectin surface.

In addition to the two flocculation models described here, at local sites on the surface of the pectin particles where a charge inversion due to the excess of adsorbed $\mathrm{Ca}^{2+}$ ions on the surface of macromolecules pectin (zeta potential $\sim 0 \mathrm{mV}$ ) was present, adsorption of the anionic PAM is also performed (Mpofy et al., 2005). Then, there is a chemical reaction between the reactive $\mathrm{COO}^{-}$group on the surface of the polyacrylamide and the adsorbed $\mathrm{Ca}^{2+}$ ions on the surface of macromolecules of pectin. Since the anionic PAMs of high molecular weight have a large length of polymer chains, after adsorption of anionic PAM, it also comes to a known "bridging effect". From Table 2, it is evident that pectin $\mathrm{P} 2$, with lower $\mathrm{DE}$, has a higher flocculating activity. This may be due to the fact that low DE pectin have higher amount of negatively charged carboxyl group ( $\left.\mathrm{COO}^{-}\right)$and could provide more effective sites for $\mathrm{Ca}^{2+}$ ions to form bridge that binds pectin particles and anionic PAM.

\section{CONCLUSIONS}

The effects of the surface charge type and molecular weight of anionic polyacrylamides (PAMs) on the zeta potential of different pectin solutions with $\mathrm{Ca}^{2+}$ ions were investigated. This work has been successful in establishing the link between electrokinetic behavior pectin solutions with $\mathrm{Ca}^{2+}$ ions, the surface charge and MW of anionic PAMs. The results indicate that some flocculation/coagulation process is 
of potential interest for the removal of pectin during sugar beet juice clarification. The main mechanism has been described by forming $\mathrm{Ca}^{2+}$ ionic bridges between anionic polymer and pectin particles. Optimum concentrations of $\mathrm{CaSO}_{4}$ (340-355 $\mathrm{mg} / \mathrm{dm}^{3}$ ) were obtained with addition of anionic PAM of the highest molar weight $\left(1500 \cdot 10^{6} \mathrm{~g} / \mathrm{mol}\right)$ and ionization degree of $30 \%$. These concentrations are many times lower compared to the conventional $\mathrm{CaO}$ coagulant $(9 \mathrm{~g} \mathrm{CaO} / \mathrm{g}$ pectin) used for purification of sugar beet juice. By using $\mathrm{CaSO}_{4}$ with the addition of this type of high molecular weight flocculant, the cost of removing pectin and other nonsucrose matter as well as the amount of waste sludge in the vicinity of the sugar factory would be reduce. This would be significant from an economic and environmental point of view.

\section{ACKNOWLEDGEMENTS}

The authors gratefully acknowledge the financial support from the Ministry of Education, Science and Technological Development of the Republic of Serbia, Project TR -31055, 2011-2018.

\section{REFERENCES}

1. Alkan, M., Karadas, M., Dogan, M., Demirbas, O. (2005). Zeta potentials of perlite samples in various electrolyte and surfactant media. Colloids and Surfaces A: Physicochemical and Engineering Aspects, 259, 155-166.

2. AOAC (2000). Methods of Analysis of Official Analytical Chemists, Washington, USA.

3. Baraniak, B.M., Swieca, M., Slowik, A. (2009). Flocculants application for precipication and separation of proteins from lens culinaris. Acta Scientiarum Polonorum Technologia Alimentaria, 8(2), 33-40.

4. Doherty, W., Fellows, O.S., Christopher, M., Gorjian, S., Senogles, E., Cheung, W.,H. (2003). Flocculation and sedimentation of cane sugar juice particles with cationic homoand copolymers. Journal of Applied Polymer Science, 90 (1), 316-325.

5. Duan, J., Gregory, J. (2003). Coagulation by hydrolyzing metal salts. Advances in Colloid and Interface Science, 100, 475-502.

6. Fraj, J. (2016). Primena protein-polimer interakcije za formiranje mikrokapsula sa kontrolisanim otpuštanjem aktivne substance. Doktorskadisertacija, Tehnološkifakultet, Novi Sad.

7. Garnier, C., Axelos, M.A.V., Thibault J.F. (1994). Selectivity and cooperativity in the binding of calcium ions by pectins. Carbohydrate Research, 256, 71-81.
8. Ghimici, L., Nichifor, M. (2018). Dextran derivatives application as flocculants, Carbohydrate Polymers, 190, 162-174.

9. Hilal, N., Al-Abri, M., Moran, A., Al-Hinai, H (2008). Effect of heavy metals and polyelectrolytes in humic substance coagulation under saline conditions. Desalination, 220, 8595.

10. Karlovič, E. (2002). Tehnologije uklanjanja prirodnih organskih materija iz vode: Prirodne materije $u$ vodi. Eds. B. Dalmacija, J. IvančevTumbas, Institut za hemiju, PMF, Novi Sad, pp. 100-113.

11. Kar, F., Arslan. N. (1999). Effect of temperature and concentration on viscosity orange peel pectin solutions and intrinsic viscositymolecular weight relationship. Carbohydrate Polymers, 40, 277-284.

12. Koper, G.J.M. (2007). An Introduction to Interfacial Engineering, VSSD, Delft.

13. Kuljanin, T. (2008). Sugar beet juice clarification by means of alternative coagulants and flocculants, $P h D$ Thesis, Faculty of Technology, University of Novi sad, Serbia.

14. Kuljanin, T., Lončar, B., Nićetin, M., Filipović, V., Knežević, V., Grbić, J. (2014). The effect of calcium sulphate, aluminium sulphate and polyelectrolyte on separation of pectin from the sugar beet juice. Journal on Processing and Energy in Agriculture, 18, (3), 119-122.

15. Kuljanin,T., Lončar, B., Nićetin M., Filipović, V., Knežević, V., Jevtić-Mučibabić, R. (2015). The effects of calcium sulphate, anionic and cationic polyelectrolyte in phase of sugar beet juice purification, Journal on processing and energy in agriculture, 19 (5), 245-248.

16. Kuljanin, T., Lončar, B., Pezo, L., Nićetin, M., Knežević, V., Jevtić-Mučibabić, R. (2015). $\mathrm{CaSO}_{4}$ and cationic polyelectrolyte as possible pectin precipitants in sugar beet juice clarification. Hemijska industrija, 69 (6), 617625.

17. Kuljanin, T., Filipović, V., Nićetin, M., Lončar, B., Muzalevski, A., Jevtić-Mučibabić R. (2016). Separation of pectin from sugar beet juice by binary system calcium sulphate/aluminium sulphate. III International Congress "Food Technology, Quality and Safety", Novi Sad, Serbia, Proceedings, pp. 565-568.

18. Lee, J., B., Schlautman, M., A., Toorman E., Fettweis, M. (2012). Competition between kaolinite flocculation and stabilization in divalent cation solutions dosed with anionic polyacrylamides. Water Research, 46, 56965706.

19. Лосева, В. А., Наумченко, И. С., Лисицкая, Р. П. (1990). Сахарная Свекла, 6, 43-44.

20. Mpofy, P., Addai-Mensah, J., Ralston J. (2005). Interfacial chemistry, particle interacttions and improved dewatering behavior of smectite clay dispersions. International Journal of Mineral Processing, 75, 155-171.

21. Mühle, K., Dobias B. (1993). Coagulation and flocculation, Ed. Marcel Dekker, New York.

22. Pattabi, S., Ramasami K., Selvam, K., Swaminathan (2000). Influence of polyelectrolytes 
on sewage water treatment using inorganic coagulants. Indian Journal Environment Protection, 20, 499-507.

23. Riddick, M.T. (1968). Zeta potential and its application to difficult water. Journal of American Waste Water Association, 1007-1030.

24. Shaikh, S.,M.,R., Nasser, M.,S., Hussein, I.,A., Benamor, A. (2017). Investigation of the effect of polyelectrolyte structure and type on the electrokinetics and flocculation behavior of bentonite dispersions. Chemical Engineering Journal, 311, 265-276.

25. Yang, R., Li, H., Huang, M., Yang, H.,Li, A. (2016). A review on chitosan-based flocculants and their applicationa in water treatment. Water Research, 95, 59-89.

\title{
УТИЦАЈ МОЛСКЕ МАСЕ И ПОВРШИНСКОГ НАЕЛЕКТРИСАҢА АНЈОНСКОГ ПОЛИАКРИЛАМИДА НА ТАЛОЖЕЊЕ ПЕКТИНА
}

\author{
Татјана А. Куљанин ${ }^{* 1}$, Владимир С. Филиповић ${ }^{1}$, Милица Р. Нићетин ${ }^{1}$, Биљана Љ. Лончар ${ }^{1}$, \\ Виолета М. Кнежевић ${ }^{1}$, Рада Ц. Јевтић Мучибабић ${ }^{2}$ \\ ${ }^{1}$ Универзитет у Новом Саду, Технолошки факултет, 21000 Нови Сад, Булевар цара Лазара 1 , \\ Србија \\ ${ }^{2}$ Универзитет у Новом Саду, Научни институт за прехрамбене технологије у Новом Саду, \\ 21000 Нови Сад, Булевар цара Лазара 1, Србија
}

Сажетак: Изнета је теоријска основа нове методе чишћења сировог сока шећерне репе базирана на примени $\mathrm{CaSO}_{4}$ уз додатак анјонског фрлокуланта, полиакриламида (ПАМ). Проучаван је утицај различитих молекулских тежина и површинског наелектрисања (степен јонизације) овог типа фрлокуланта на таложење пектина. Мерењем зета потенцијала, установљена је неутрализација наелектрисања пектинских макромолекула и процес међучестичног повезивања. Процес међучестичног повезивања је описан преко два механизма: стварање $\mathrm{Ca}^{2+}$ "мостова" између анјонских полимерних ланаца и пектинских макромолекула и стварање $\mathrm{Ca}^{2+}$ "мостова" само између анјонских полимера. Испитивано је 10 концентрација $\mathrm{CaSO}_{4}$ уз додатак ПАМ-а молекулских тежина: $500 \cdot 10^{6} ; 1000 \cdot 10^{6}$ и $1500 \cdot 10^{6} \mathrm{~g} / \mathrm{mol}$, концентрације $3 \mathrm{mg} / \mathrm{dm}^{3}$. Установљено је, да се са порастом молекулске тежине анјонског полимера, интензивира стварање $\mathrm{Ca}^{2+}$ "мостова" између ПАМ-а и пектинских макромолекула чиме се побољшава њихова коагулација.

Оптималне концентрације $\mathrm{CaSO}_{4}\left(340-355 \mathrm{mg} / \mathrm{dm}^{3}\right)$, постижу се у тренутку разелектрисања површине пектинских макромолекула када је достигнута нулта вредност зета потенцијала. Најбољи резултати добијени су применом $\mathrm{CaSO}_{4}$ уз анјонски ПАМ највеће молске масе $(1500$. $10^{6} \mathrm{~g} / \mathrm{mol}$ ) и степена јонизације $30 \%$.

Количина $\mathrm{CaSO}_{4}$ уз додатак овог типа фрлокуланта велике молекулске тежине, била би вишеструко мања у поређењу са употребљеном количином класичног коагуланта СаO (око $9 \mathrm{~g} / \mathrm{g}$ пектина у соку шећерне репе). Самим тим, смањили би се трошкови уклањања пектина и других несахарозних материја из сока шећерне репе као и количина отпадног муља у непосредној близини фрабрике шећера. јонизације

Кључне речи: пектини, $\mathrm{CaSO}_{4}$, анјонски полиакриламид, молекулска тежина, степен

Received: 11 July 2018

Received in revised form: 2 October 2018

Accepted: 9 November 2018 